

Rodrigo de Sousa Oliveira ${ }^{\mathrm{la}, 2+}$, Túllio Morais Franca ${ }^{2 \mathrm{a}}$

\title{
CLIMATE ZONING FOR THE CULTIVATION OF AFRICAN MAHOGANY SPECIES IN BRAZIL
}

OLIVEIRA, R. de S.; FRANCA, T. M. Climate zoning for the cultivation of African Mahogany species in Brazil. CERNE, v. 26, n. 3, p.369-380, 2020.

\section{HIGHLIGHTS}

Keywords:

Climatic aptitude

Khaya

Rainfall

Temperature

Historic:

Received 14/05/2020 Accepted 07/08/2020

+Correspondence: rodrigodesousal2@gmail.com
Brazil has high climatic aptitude for African mahogany species.

K. anthotheca and K. grandifoliola show high aptitude in more than $70 \%$ of Brazil.

K. ivorensis presented the lowest proportion of area with high fitness to the planting.

K. senegalensis is the most sensitive species to low temperatures.

\section{ABSTRACT}

African mahogany is the common name given to different species of the genus Khaya. They are tree species native to the African continent, which have a wood quality that allows their noble use in making fine furniture, and in the civil and naval industries. Currently, African mahogany cultivation has received notoriety in Brazil and given its climatic conditions. The country has great potential for planting these species. The purpose of this work was to identify climatic aptitude zones for African mahogany in Brazil. Based on the Kppen classification and in the means of relative air temperature and annual rainfall, a base map interpolation was performed to select regions suitable and restricted to planting and adequate growth of African mahogany species. In general, the regions that presented temperatures between $22^{\circ} \mathrm{C}$ and $30^{\circ} \mathrm{C}$ were considered of high fitness, while temperature values below $14{ }^{\circ} \mathrm{C}$ restricts plantations growth. Regarding to precipitation, areas considered to be of high aptitude have between 700 to $3,000 \mathrm{~mm} \cdot y e a r^{-1}$, extreme values may indicate regions of low suitability and restricted to the cultivation of African mahogany. From the climatic characteristics, it was determined that about $60 \%$ of the Brazilian area was of high fitness, between $16 \%$ and $32 \%$ of medium fitness, and less than $20 \%$ as low fitness. The Northeastern semi-arid region proved to be restricted to the cultivation of these species due to the low annual rainfall and a few places in the South region was also restricted due to low temperatures and risks of frost. 


\section{INTRODUCTION}

Wood product has great and worldwide demand, which stimulates the production and cutting of trees that have economic importance. The predatory exploitation has caused the degradation of several Brazilian biomes, increasing the risk of extinction of timber forest species, such as Araucaria angustifolia (Bertol.) Kuntze, Cedrela fissilis Vell., Dinizia excelsa Ducke, Dipteryx odorata (Aubl.) Willd., Hymenaea courbaril L., Swietenia macrophylla King, Handroanthus serratifolius (Vahl) S.Grose, among others (IUCN, 2018; Brandes et al., 2020). The Amazon region has increasing deforestation rates, reaching maximum levels in 2004 and 2019 (INPE, 2020). An alternative to reduce illegal deforestation in native areas is the use of wood from commercial plantations of forest species in addition to the sustainable forest management.

The implantation of commercial forests has been a new market trend, as they are important for reducing the forest deficit, protecting remaining native areas, fixing atmospheric carbon, and regulating the hydrological cycle (Grattapaglia and Kirst, 2008; Payn et al., 20I5). In 20I8, Brazil had about 7.83 million hectares of commercial forests that serve to several economic purposes (IBÁ, 2019). The Eucalyptus spp. and Pinus spp. occupy $72.4 \%$ and $20.1 \%$, respectively, of this planted area, while species destined exclusively for sawnwood use, such as those of the genus Khaya A. H. L. De Juss, represent less than 5\% (IBÁ, 20I9).

The K. anthotheca (Welw.) C. DC., K. ivorensis A. Chev., K. grandifoliola C. DC. and K. senegalensis (Desr.) A. Juss. are known as African mahogany (Lamprecht, 1990; Opuni-Frimpong et al., 2008; Reis et al., 2019b). They are large trees belonging to Meliaceae's family, with extensive stem, dense crown, and wood quality for noble uses Opuni-Frimpong et al., 2016; Dipelet et al., 2019; Pakull et al., 2019). African mahogany has been increasingly used by reforesters in Brazil, due to the advances in producing seedlings, the fast growth, and the high economic value of wood in the international market (Falesi and Baena, 1999; Ribeiro et al., 2017; ITTO, 2020). It is estimated that the Brazilian territory has more than 37 thousand hectares, making Brazil the world's largest reforestation of African mahogany (Reis et al., 2019b).

Another factor that boosted the cultivation of African mahogany was the prohibition on the exploitation of wood Brazilian mahogany, S. macrophylla (Gasparotto et al., 200I; Couto et al., 2004; Brasil, 2008). Was believed African mahogany to have total resistance to Hypsipyla grandella Zeller, the shoot borer, that causes wood damage, common in Brazilian mahogany (Poltronieri et al., 2002; Krisnawati et al., 20I I). However, a few attacks by $H$. grandella have already been reported, punctually, in $K$. ivorensis plantations (Zanetti et al., 2017; Lemes et al., 2019), not restricting the technical and economic advantages for planting these species in Brazil.

Commercial forests may be responsible for meeting not only the demand for timber products, but also products such as resins and medicines. African mahogany has antifungal, anti-inflammatory, insecticidal, and preventive compounds against malaria and other diseases (Nikiema and Pasternak, 2008; Zhang et al., 2009; Abdel-Wareth et al., 2014). The adaptation and production of commercial forests is directly influenced by climatic conditions. To obtain greater forest productivity, adjustments in silvicultural treatments, promotion of genetic improvement of the species used and the search for better climatic adaptation are necessary.

Climatic variables, such as air temperature and rainfall, are influenced by other factors e.g. geographical relief, altitude, and vegetation (Alvares et al., 20l3b). Thus, the climate is a limiting and conditioning factor for the commercial planting of forest species. The climate is the condition with the least chance of intervention, allowing only some control in small and protected areas, such as greenhouses (Casaroli et al., 2018).

Except for the species $K$. ivorensis, information is lacking that portrays the ideal climatic conditions to guide African mahogany plantations in Brazil. K. ivorensis already had a climatic zoning elaborated by Derblai et al. (2018). However, recently in Brazil, K. ivorensis has come by a correction in its botanical classification, being called K. grandifoliola (ABPMA, 2020). Thus, the zoning proposed by Derblai et al. (20I8), must also be reviewed.

Climatic zoning is an important tool for choosing species and silvicultural treatments in a region, promoting the best use of the natural resources available. Therefore, climatic zoning is fundamental in decision-making, as it assesses the compatibility between species and the cultivation environment, in order to delimit regions that provide greater or lesser fitness, defining areas with foremost potential for implantation (Golfari et al., 1978). Under these circumstances, the objective of this work was to carry out climatic zoning for the different species of African mahogany cultivated in Brazil, aiming to give subsidies regarding to the indication of potentially species suitable for plantation in different Brazilian regions.

\section{MATERIAL AND METHODS}

The determination of zones with greater or lesser climatic fitness of the different species of African mahogany planted in Brazil (K. anthotheca, K. grandifoliola, K. ivorensis and $K$. senegalensis) was based on climatic characteristics 
of the naturally occurring areas of these species (Figure I). Climatic data were collected from all countries where African mahogany species occur (CJBG and SANBI, 20I2; Bouka et al., 2019). In those areas there are several climatic typologies described by Köppen and Geiger (1928), standing out the types Af, Am, Aw and Bsh (Table I).

The climatic aptitude criteria for each of the species evaluated were established based on the climatic characteristics of the places of natural occurrence of the populations of Khaya spp. (Table 2). The African mahogany species evaluated have a wide distribution in the African continent (Figure I). The intervals of the averages of the optimal values of air mean temperature, annual rainfall, and altitude in the naturally occurring environments of each species were considered as. Values outside the optimal development limits were considered to have low tree growth capacity.
To classify climatic suitable zones for African mahogany species in the national territory, climatic data from 557I Brazilian municipalities were used. The values of altitude, temperature, and rainfall represent the average of the pixels $(100 \mathrm{~m})$ within the perimeter of each municipality. Only the most representative Köppen climate type (\% in area) was considered in each municipality. These climatic data were made available by IPEF (2020).

The temperature values were obtained by Alvares et al. (2013a) through a model produced by ordinary kriging from the average of the temperature data of 2,400 weather stations. These temperature predictor model had an excellent performance $\left(R^{2}=0.93\right.$, RMSE $=0.80^{\circ} \mathrm{C}$, DW statistical test $\left.=2.0 \mathrm{I}\right)$. The altitudes were generated by Alvares et al. (2013a) by the digital elevation model (DEM) from SRTM images (Shuttle

TABLE I Interval of average annual rainfall $(\mathrm{mm})$ and average annual temperature $\left({ }^{\circ} \mathrm{C}\right)$ and Kppen-Geiger climate classification predominant for the countries that form the regions of origin of the African mahogany species (Khaya ssp.).

\begin{tabular}{|c|c|c|c|c|c|c|c|}
\hline Countries & Rainfall (mm) & Temp. $\left({ }^{\circ} \mathrm{C}\right)$ & $\begin{array}{c}\text { Climate Classification of } \\
\text { Kppen-Geiger }\end{array}$ & $\begin{array}{c}\text { Khaya } \\
\text { anthotheca }\end{array}$ & $\begin{array}{c}\text { Khaya } \\
\text { grandifoliola }\end{array}$ & $\begin{array}{l}\text { Khaya } \\
\text { ivorensis }\end{array}$ & $\begin{array}{c}\text { Khaya } \\
\text { senegalensis }\end{array}$ \\
\hline Angola & $1500-2000$ & $21-23$ & Aw & $x$ & & & \\
\hline Benin & $1500-2000$ & $27-28$ & Aw & $x$ & $x$ & & $x$ \\
\hline Burkina Faso & $1000-2000$ & $27-28$ & Aw, BSh & $x$ & & & $x$ \\
\hline Burumbi & $1000-1500$ & $21-23$ & Aw & $x$ & & & \\
\hline Cameroon & $2000->3000$ & $23-26$ & Am, Aw, BSh & $x$ & $x$ & $x$ & $x$ \\
\hline Central African Republic & $1500-3000$ & $24-26$ & Aw & $x$ & $x$ & & $x$ \\
\hline Chad & $600-2000$ & $26-27$ & Aw, BSh & & & & $x$ \\
\hline Congo & $2000-3000$ & $23-26$ & $A m, A w$ & $x$ & & $x$ & \\
\hline Côte d'ivoíre & $1500-3000$ & $24-25$ & $\mathrm{Am}, \mathrm{Aw}$ & $x$ & $x$ & $x$ & $x$ \\
\hline Democratic Republic of the Congo & $1000->3000$ & $22-26$ & Af, Am, Aw, Cwa, Cwb & $x$ & $x$ & $x$ & $x$ \\
\hline Equatorial Guinea & $>3000$ & $23-24$ & Am & & & $x$ & \\
\hline Gabon & $2000->3000$ & $24-26$ & $A m, A w$ & & & $x$ & $x$ \\
\hline Gambia & $1500-2000$ & $26-28$ & Aw & & & & $x$ \\
\hline Ghana & $1500-3000$ & $26-27$ & $A m, A w$ & $x$ & $x$ & $x$ & $x$ \\
\hline Guinea & $2000-3000$ & $25-26$ & $A m, A w$ & $x$ & $x$ & $x$ & $x$ \\
\hline Guinea Bissau & $1500-2000$ & $25-26$ & Aw & & & & $x$ \\
\hline Kenya & $1000-1500$ & $25-26$ & Aw & $x$ & & & \\
\hline Liberia & $>3000$ & $24-25$ & Af, Am & $x$ & $x$ & $x$ & \\
\hline Malawi & $600-1500$ & $21-24$ & BSh, Cwa, Cwb & $x$ & & & \\
\hline Mali & $1000-3000$ & $26-28$ & Aw, BSh & & & & $x$ \\
\hline Mozambique & $600-1500$ & $23-25$ & Aw, BSh & $x$ & & & \\
\hline Niger & $1000-1500$ & $27-29$ & BSh & & & & $x$ \\
\hline Nigeria & $1000->3000$ & $25-27$ & Am, Aw, BSh & $x$ & $x$ & $x$ & $x$ \\
\hline Senegal & $1000-3000$ & $26-29$ & Aw, BSh & & & & $x$ \\
\hline Sierra Leone & $>3000$ & $25-26$ & $\mathrm{Am}$ & $x$ & $x$ & & $x$ \\
\hline South Sudan & $1000-2000$ & $23-28$ & Aw & & $x$ & & $x$ \\
\hline Sudan & $400-1000$ & $23-29$ & Bsh, BWh & & & & $x$ \\
\hline Tanzania & $600-2000$ & $20-26$ & Aw, BSh, Cwa & $x$ & $x$ & & \\
\hline Togo & $1000-3000$ & $25-28$ & Aw & $x$ & $x$ & $x$ & $x$ \\
\hline Uganda & $1000-3000$ & $22-24$ & $A m, A w$ & $x$ & $x$ & & $x$ \\
\hline Zambia & $600-2000$ & $20-25$ & Aw, BSh, Cwb & $x$ & & & \\
\hline Zimbabwe & $600-1500$ & $22-23$ & BSh, Cwb & $x$ & & & \\
\hline
\end{tabular}

Source: Kppen and Geiger (1928); Kottek et al. (2006); FreeMeteo (2020). Af: Tropical rainforest climate; Am: Tropical monsoon climate; Aw: Tropical savanna climate dry-winter characteristics; BSh: Hot Semi-arid climate;; BWh: Arid climate; Cfa: Humid subtropical climates; Cfb: Oceanic climate; Cwa: Dry-winter humid subtropical climate; Cwb: Dry-winter subtropical highland climate. 
TABLE 2 Classes of climatic aptitude for the cultivation of the different species of African mahogany (Khaya spp), based on their areas of natural distribution.

\begin{tabular}{|c|c|c|c|c|c|c|c|c|c|c|}
\hline \multirow[t]{2}{*}{$\begin{array}{c}\text { African Mahogany } \\
\text { Species }\end{array}$} & \multicolumn{3}{|c|}{ Rainfall (mm) } & \multicolumn{3}{|c|}{ Temperature $\left({ }^{\circ} \mathrm{C}\right)$} & \multicolumn{3}{|c|}{ Altitude (m) } & \multirow{2}{*}{$\begin{array}{c}\text { Köppen Climate } \\
\text { Types }\end{array}$} \\
\hline & High Aptitude & Low Aptitude & Unapt & $\begin{array}{c}\text { High } \\
\text { Aptitude }\end{array}$ & $\begin{array}{c}\text { Low } \\
\text { Aptitude }\end{array}$ & Unapt & $\begin{array}{c}\text { High } \\
\text { Aptitude }\end{array}$ & Low Aptitude & Unapt & \\
\hline K. anthotheca & $1,000-3,250$ & $\begin{array}{c}600-999 \text { or } \\
>3,250\end{array}$ & $<600$ & $21-28$ & $\begin{array}{c}<21 \\
\text { or }>28\end{array}$ & $<12.5$ & $0-I, 800$ & $\mathrm{I}, 800-2,200$ & $>2,200$ & $\begin{array}{l}\text { Af, Am, Aw, BSh, } \\
\text { Cwa, Cwb }\end{array}$ \\
\hline K. grandifoliola & $1,000-3,100$ & $\begin{array}{c}760-999 \text { or } \\
>3,100\end{array}$ & $<760$ & $22-28$ & $\begin{array}{c}<22 \\
\text { or }>28\end{array}$ & $<12.7$ & $200-1,800$ & $\begin{array}{c}<200 \text { or } 1,800- \\
2,200\end{array}$ & $>2,200$ & Af, Am, Aw \\
\hline K. ivorensis & $\mathrm{I}, 500-3,250$ & $\begin{array}{c}815-1499 \text { or } \\
>3,250\end{array}$ & $<815$ & $22-28$ & $\begin{array}{c}<22 \\
\text { or }>28\end{array}$ & $<13.0$ & $0-800$ & $800-I, 200$ & $>1,200$ & Af, Am, Aw \\
\hline K. senegalensis & $1,000-3,000$ & $\begin{array}{c}560-999 \text { or } \\
>3,000\end{array}$ & $<560$ & $23-29$ & $\begin{array}{c}<23 \\
\text { or }>29\end{array}$ & $<13.5$ & $0-1,800$ & $1,800-2,200$ & $>2,200$ & $\begin{array}{c}\text { Am, Aw, BSh, } \\
\text { BWh }\end{array}$ \\
\hline
\end{tabular}

Source: Lamprecht, 1990; Preciak et al., 2013; Opuni-Frimpong et al., 2016; Reis et al., 2019a. Af: Tropical rainforest climate; Am: Tropical monsoon climate; Aw: Tropical savanna climate dry-winter characteristics; BSh: Hot Semi-arid climate; BWh: Arid climate; Cwa: Dry-winter humid subtropical climate; Cwb: Dry-winter subtropical highland climate.

Radar Topography Mission) in GEOTIFF format with spatial resolution of 90 meters and SIRGAS2000 datum (Jarvis et al., 2008; Farr and Kobrick, 2000).

Precipitation values were obtained by Alvares et. al. (20I3b) through a punctual ordinary kriging estimator was used for geostatistical interpolation from data to 2,950 weather stations distributed throughout the Brazilian territory. These rainfall estimators had an excellent performance, with the estimated residues were low and a high coefficient of determination $\left(R^{2}\right)$, above 0.97 , and a strong SDI, spatial dependence index (Alvares et al., 20I3b).

Alvares et al. (20/3b) found 12 types Köppen climates throughout Brazil, being: Af, Am, Aw, As, BSh,

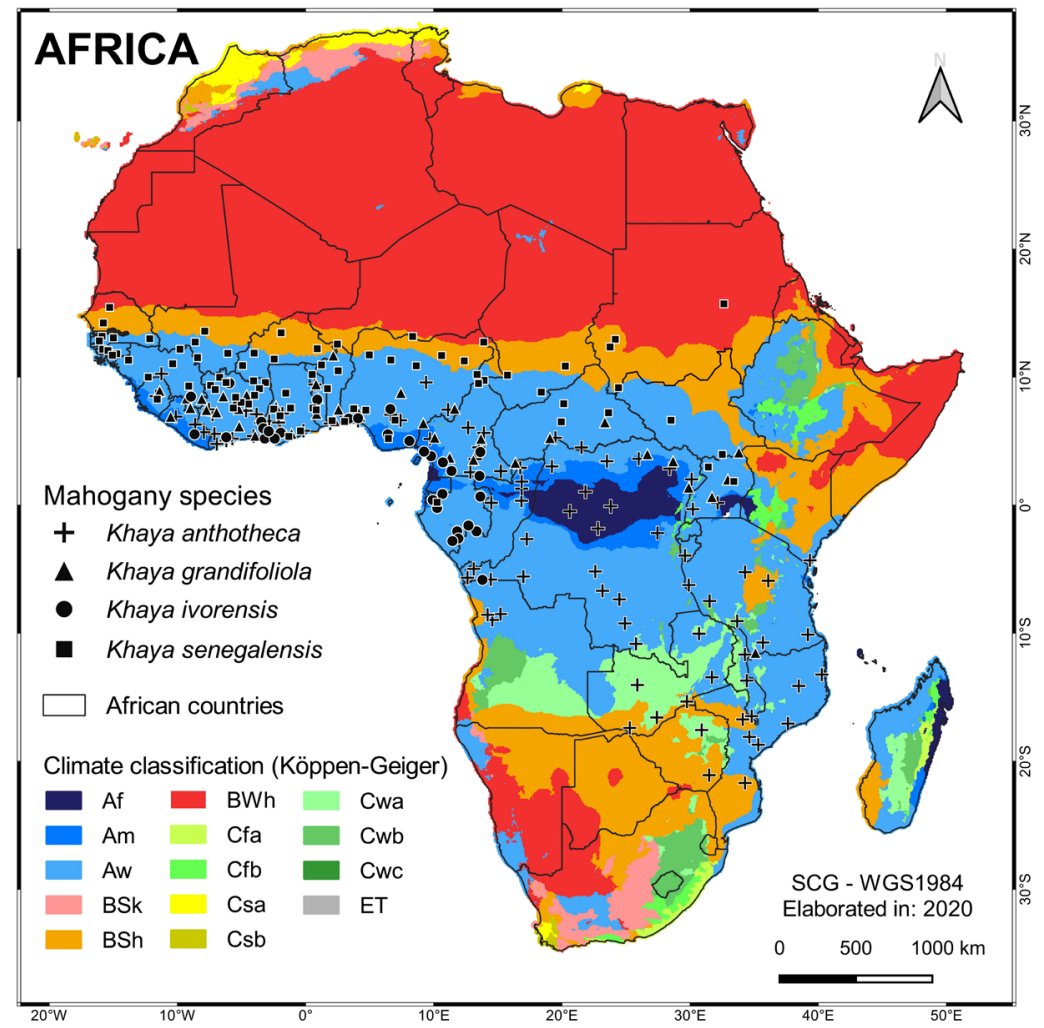

FIGURE I Area of natural occurrence of African mahogany species and Kppen-Geiger climate classification for the African continent. Source: Kppen and Geiger (1928); Kottek et al. (2006); CJBG and SANBI (20I2); Dipelet et al. (20I9). Af: Tropical rainforest climate; Am: Tropical monsoon climate; Aw: Tropical savanna climate dry-winter characteristics; BSh: Hot Semiarid climate; BSk: Cold Semi-arid climate; BWh: Arid climate; Cfa: Humid subtropical climates; Cfb: Oceanic climate; Csa: Mediterranean hot summer climates; Csb: Mediterranean cool summer climates; Cwa: Dry-winter humid subtropical climate; Cwb: Dry-winter subtropical highland climate; Cwc: Dry-winter subpolar oceanic climate; ET: Tundra climate. 



FIGURE 2 Base map of climate classification in Brazil at the municipal boundary: A) Köppen-Geiger climate classification; B) map of average annual temperatures $\left.\left({ }^{\circ} \mathrm{C}\right) ; \mathrm{C}\right)$ annual rainfall map (mm year'); $\mathrm{D}$ ) map of maximum annual mean temperatures $\left({ }^{\circ} \mathrm{C}\right)$; E) map of altitudes (m); F) map of minimum annual mean temperatures $\left({ }^{\circ} \mathrm{C}\right)$. Source: Köppen and Geiger (1928); Alvares et al. (20I3b); IBGE (2018); INMET (2020); IPEF (2020). Af: Tropical rainforest climate; Am: Tropical monsoon climate; Aw: Tropical savanna climate dry-winter characteristics; As: Tropical savanna climate dry-summer characteristics; BSh: Hot Semi-arid climate; Cfa: Humid subtropical climates; Cfb: Oceanic climate; Cwa: Dry-winter humid subtropical climate; Cwb: Dry-winter subtropical highland climate. 
Cfa, Cfb, Cwa, Cwb, Cwc, Csa and Csb (Figure 2). These Köppen climate types are symbolized by two or three characters, where the first indicates the climate zone and is defined by temperature and rainfall, the second considers the rainfall distribution and the third is the seasonal temperature variation. The layers of latitude and longitude were obtained in decimal degrees using the central coordinates of each pixel.

The base maps of the Köppen altitude, temperature, rainfall, and climate type values were built respecting the perimeter of each municipality (Figure 2), according to the climatic data obtained by Alvares et al. (20I3b) and available by IPEF (2020). From the union of information on the climatic requirements of the species of Khaya spp. assessed and the conditions of the Brazilian climates (Figure 2), classes of aptitude were created to recommend the best environments for the development of each species.

Through the base maps it was possible to create maps of climatic fitness for each species through boolean overlay, through the union of information on their climatic requirements using the pre-established criteria (Table 2). The boolean overlay method is one of the simplest for making thematic maps (Riad et al., 20I I; Palmer et al., 2019). This technique is great for dealing with environmental data, because boolean overlays allow to combine several thematic maps to generate another one reflecting these combined information (Watson \& Hudson, 2015; Palmer et al., 2019; Cao et al., 2019).

Thus, five aptitude classes were created, three for suitable environments and two for restricted or unfit use. In environments favorable to planting, the classes are subdivided into high, mean and low aptitude. The high climatic aptitude for the African mahogany species comprises the high aptitude classes for each variable considered. The medium aptitude comprises classes of high aptitude and medium aptitude, whereas the low aptitude comprises the classes of low aptitude for all the considered characteristics. Low annual rainfall favors ineptitude due to water deficit, while low temperatures can restrict the vegetative development of plants, especially when frost occurs.

The climate fitness maps for African mahogany were generated using Geographic Information Systems (GIS) in the free software QGIS 3.I4.I Pi (QGIS, 2020).

\section{RESULTS}

The species $K$. anthotheca showed high climatic aptitude in $77.6 \%$ of the national territory, based on annual rainfall, temperature averages, altitude and Köppen climate types considered in this study. These high climatic aptitude areas are concentrated in the Midwest region (DF, GO, MS and MT states), North (AC, AM, AP, PA, RO, RR and TO states), Southeast (ES, MG, $\mathrm{RJ}$ and $\mathrm{SP}$ ) and the Northeast coast (Figure $3 \mathrm{~A}$ ).

Areas with mean aptitude represent $10.3 \%$ of the Brazilian territory, while $7.7 \%$ are areas with low fitness. The mean aptitude is identified in part of the states in the North (AM and AP states) and South (PR and SC states) regions, and in all states in the Northeast and Southeast regions. Areas of low aptitude for $K$. anthotheca are concentrated in the interior of the Northeast region (AL, $\mathrm{BA}, \mathrm{CE}, \mathrm{MA}, \mathrm{PB}, \mathrm{PE}, \mathrm{PI}, \mathrm{RN}$ and SE states) and in the South region (PR, RS and SC states), surrounding the restricted areas to the development of $K$. anthotheca.

Favorable growth restrictions are due to low annual rainfall in the Northeast and low average air temperatures in the South. These restricted areas correspond to $2.3 \%$ and $2.1 \%$ of the national territory, respectively.

The species $K$. grandifoliola showed high climatic fitness for all the Midwest region, almost all the North region, as well as the Northeast coast and part of the Southeast region, which corresponds to about $72 \%$ of the Brazilian territory (Figure 3B). Areas with mean aptitude for $K$. grandifoliola are found in parts of the AM, MA, PR, SP, MG, RJ, ES and PI states, which consist of $10.5 \%$ of the country.

The low aptitude of the species reaches only $9.3 \%$ of Brazilian territory, in areas in the South and Northeast, north of AP state and far west of AM state. The restrictions on the good development of $K$. grandifoliola are due to the low annual rainfall in the Northeast and the low average air temperatures in the South, which together make its growth impossible in $8 \%$ of the national territory.

The species $K$. ivorensis also showed high climatic aptitude in $62,8 \%$ of Brazilian territory, including the Midwest and North regions, except for part of the MT, MS, AM, AP and TO states (Figure 3C). The areas with mean aptitude for $K$. ivorensis account for $13.2 \%$ of the national territory and represent a transition zone between the high and low aptitude areas. The low aptitude areas represent $14 \%$ of the Brazilian area, concentrated in most part of the South, Southeast regions and Northeast and northwest of AM state. Among the species evaluated, $K$. ivorensis has the largest area of planting restriction, being $2.9 \%$ due to the occurrence low temperatures and $7.1 \%$ due to water deficiency, concentrated in the northeast region (Figure 3C).

The species $K$. senegalensis shows high climatic aptitude in $68.1 \%$ of the Brazilian territory, including 

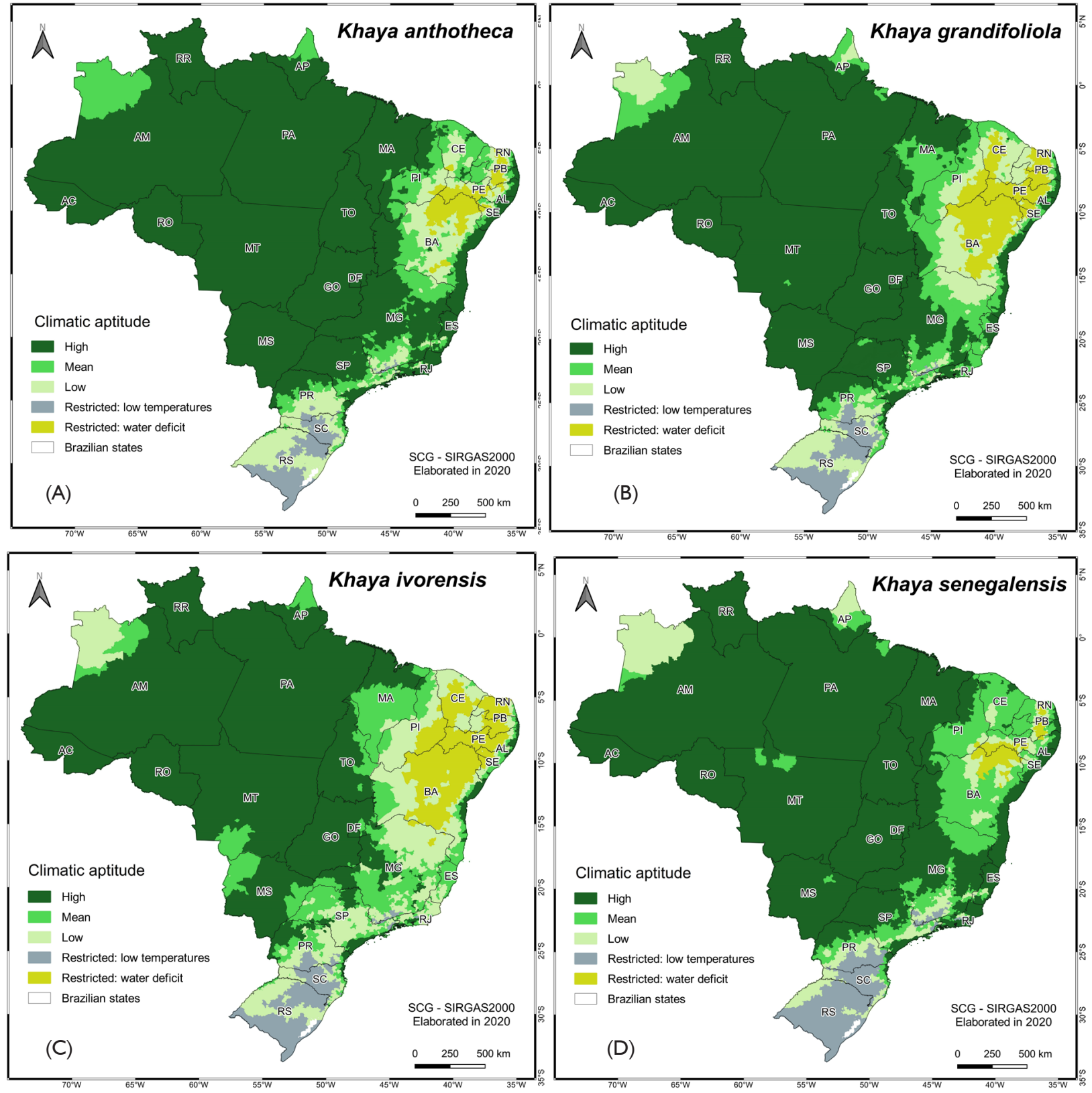

FIGURE 3 Climatic aptitude map for Khaya spp species in Brazil. A: Khaya anthotheca; B: Khaya grandifoliola; C: Khaya ivorensis; D: Khaya senegalensis. Source: Alvares et al. (20I3b); IBGE (20I8); INMET (2020); IPEF (2020). AC: Acre; AL: Alagoas; AM: Amazonas; AP: Amapá; BA: Bahia; CE: Ceará; DF: Distrito Federal; ES: Espírito Santo; GO: Goiás; MA: Maranhão; MG: Minas Gerais; MT: Mato Grosso; MS: Mato Grosso do Sul; PA: Pará; PB: Paraíba; PE: Pernambuco; PI: Piauí; PR: Paraná; RJ: Rio de Janeiro; RN: Rio Grande do Norte; RO: Rondônia; RR: Roraima; RS: Rio Grande do Sul; SC: Santa Catarina; SE: Sergipe; SP: São Paulo; TO: Tocantins.

almost the totality North, Southeast and Midwest regions, in addition to MA state and the Northeast coast (Figure 3D). The areas with mean climatic aptitude for $K$. senegalensis are concentrated in the Northeast region, north of MG state and in narrow lanes in PR and SP states, and south MG state, totaling $22.6 \%$ of the national area.

The areas with low fitness, however, account for only $4.7 \%$ of the Brazilian territory, being distributed in the north of Amapá and Amazonas and in small parts in the South, Southeast and Northeast regions. $K$. senegalensis has the lowest restriction in relation to water deficit, about $1.6 \%$ of the total area, and $3 \%$ of Brazil. This species presents restriction of $4.43 \%$ of Brazilian territory area is due to low temperatures.

\section{DISCUSSION}

When considering the climatic variables and the geographical relief, it is noted that Brazil is predominantly 
suitable for all the observed African mahogany species. The $K$. anthotheca species originally occurs in several vegetation formations, from wet to dry semideciduous forests, and in transition areas between these and the savanna, in addition to perennial wet forests (Maroyi, 2008; Opuni-Frimpong et al., 2016; Reis et al., 2019a).

$K$. anthotheca grows well in fertile, deep moist or well-drained soils, as is the majority of Brazilian soils (Santos et al., 2018) and does not occur at high altitudes (Maroyi, 2008; Praciak et al., 2013).Therefore, $K$. anthotheca has the capacity to adapt in different environments and throughout Brazil (Figure 3), as it is the species with the greatest territorial coverage in the African continent (Figure I).

Until recently, the species $K$. grandifoliola was classified in Brazil as $K$. ivorensis, due to its botanical similarities and anatomical properties of wood (ABPMA, 2020; Dipelet et al., 2019). Therefore, some studies have reported silvicultural aspects such as productivity and adaptation of $K$. grandifoliola as being of $K$. ivorensis (Ribeiro, et al. 2017, Casaroli et al., 2018).

Until the present moment, this is one of the first studies that reports the aspects of climatic adaptation, with the true naturally occurring environments of $K$. grandifoliola (Figure I and Table I). Among the African mahogany species evaluated, $K$. grandifoliola is the most planted in Brazil, owing to its rapid growth, showing high potential for cultivation in the country, since $72.2 \%$ of the national territory has high aptitude for planting (Figure B).

The species $K$. grandifoliola has a smaller territorial distribution in the African continent than $K$. anthotheca but is found in several environments such as savanna formations and semideciduous forests (Opuni-Frimpong, 2008; Praciak et al., 20I3). This fact probably explains the high fitness found in Brazil, mainly in the regions under the influence of the Cerrado, Amazon Forest and Atlantic Forest biomes and their transition zones.

The species $K$. grandifoliola presents good development in well-drained soils, the majority of Brazilian soils (Santos et al., 2018), and just like $K$. anthotheca, can support long periods of drought (OpuniFrimpong et al., 20I6), which reiterates its high suitability in the Cerrado biome.

Among the species evaluated, $K$. ivorensis is the one with the smallest extension of natural area, occurring at low-lying humid tropical regions (Lampecht, 1990; Lemmens, 2008; Opuni-Frimpong et al., 2016). This species is, currently, the most endangered and over the years, and even today, it has been the most commercially exploited (IUCN, 20I8; ITTO, 2020). In Brazil, K. ivorensis was the one with the lowest proportion of high aptitude, corresponding to $62.8 \%$ of the country's area (Figure 3C).

$K$. ivorensis has a good development in perennial and semideciduous forests (Lemmens, 2008; Reis et al., 2019a). Thus, this species has a good capacity for adaptation in regions such as the Cerrado and its transition areas with other biomes, as long as it is not in places with long periods of severe drought (Lamprecht, 1990), which explains the high aptitude in a great extension of Brazil (Figure 3C).

The area of natural occurrence of $K$. senegalensis covers a wide area in the transition zone between SubSaharan Africa and tropical forests as can be seen in the figure I (Lamprecht, 1990; Nikiema and Pastenak, 2008; Praciak et al., 20/3). K. senegalensis showed high fitness in $68.1 \%$ of the Brazilian territory (Figure 3D). Although it is not the species with the greatest aptitude, it is the least restrictive to water deficit due to its natural occurrence in sites with warmer and arid climates than the other species (Figure I and Table I).

According to Matos et al. (2016) the species K. senegalensis adapts to moderate water deficits, that as it occurs in a good part of the Northeastern semiarid. Thus, among the species evaluated, $K$. senegalensis is the one with the best performance in areas under the influence of the Caatinga biome, and, also in the areas of sandy soils and subject to water deficit, characteristics of the Cerrado biome.

The areas with mean fitness reflect that the rainfall or average air temperature are outside the optimal levels, while the areas with low fitness reflect both criteria below the desired levels (Table 2). The restricted areas, on the other hand, make the growth and development of these African mahogany species infeasible at certain times of the year, with low temperatures or low rainfall.

One of the basic factors that guarantees the success of reforestation is the use of adapted species to climatic conditions. Thus, the relation of the classification of the Brazilian territory to its aptitude to cultivate the different species of African mahogany is fundamental to guide future plantations regarding the choice of species to be used.

The cultivation of African mahogany (Khaya spp.) in Brazil continues to expand, going from just over 10,000 hectares in 2017 to around 37 thousand hectares in 2018 (Ribeiro et al., 2017; Reis et al., 2019b). Most of these plantations are of the species $K$. grandifoliola and $K$. ivorensis (ABPMA, 2020). With the recent reclassification, in Brazil, from the species $K$. ivorensis to $K$. grandifoliola 
(ABPMA, 2020), it is still imprecise to distinguish which is the real planted area of each species.

This botanical divergence has implications for the correct indication of the best planting sites for certain species. This is due to the fact that wood of $K$. ivorensis, $K$. anthotheca and $K$. grandifoliola are similar and exported in mixed consignments such as African mahogany with similar commercial value in the international market (Maroyi, 2008; Ribeiro et al., 2019; ITTO, 2020).

African mahogany has great variability between species and individuals in native areas and in commercial plantations of seminal origin (Sexton et al., 2015; Soares et al., 2020). The genotypes commercialized in Brazil may not reflect all the existing genetic variability and in consequence, there may be reports of poor silvicultural performance of the species assessed in areas of high climatic aptitude.

The genus Khaya is still in the wild, with excellent potential for genetic improvement (Nikles et al., 2008). Taking advantage of the variability existing in natural or cultivated populations, strategies for conservation, domestication and silvicultural improvement of these species can be established (Lemes et al., 20ll). Thus, it is possible to explore this variability to maximize the species aptitude in different climatic and edaphic conditions (Chaikaew et al., 2020). To date, there are no genetic breeding programs for the genus Khaya in Brazil (Soares et al., 2020).

In the face of climate and social changes, commercial forest plantations for solid wood are the future guarantee of wood supply, being able to provide all the world demand for wood (Chisika \& Yeom, 2020). The area planted with African mahogany is increasing in Brazil and in the world (Reis et al., 2019b).

To keep increasing the plantations of Khaya spp. it is necessary to know suitable regions suitable for cultivation of these species, to maximize your productivity. Through this study it is possible to select suitable regions to planting the different species evaluated to maximize productivity of the African mahogany throughout the national territory.

\section{CONCLUSION}

It was observed that in Brazil there is a high aptitude for all species of African mahogany, mainly to $K$. anthotheca and $K$. grandifoliola.

Therefore, African mahogany cultivation must be encouraged and continued in Brazil, as well as the development of breeding programs, paying attention to the better use of the existing climatic zoning.
It is recommended that other studies with climatic zoning and soil analyzes for African mahogany should be carried out in conjunction with surveys of species productivity in loco.

\section{ACKNOWLEDGEMENT}

To the company Mudas Nobres for financial support, and the opportunity to research African Mahogany species.

\section{REFERENCES}

ABDEL-WARETH, A. A. A.; HAMMAD, S.; AHMED, H. Effects of Khaya senegalensis leaves on performance, carcass traits, hematological and biochemical parameters in rabbits. EXCLI Journal, v. I3, p. 502-5I2, 2014.

ABPMA. Associação Brasileira dos Produtores de Mogno Africano. Dr. Ulrich Gal e a Khaya grandifoliola no Brasil. ABPMA, 2020. 21 p.

ALVARES, C. A.; STAPE, J. L.; SENTELHA, P. C.; GONÇALVES, J. L. M. Modeling monthly mean air temperature for Brazil. Theoretical and Applied Climatology, v. I I3, p. 407$427,2013 a$.

ALVARES, C. A.; STAPE, J. L.; SENTELHA, P. C.; GONÇALVES, J. L. M.; SPAROVECK, G. Köppen's climate classification map for Brazil. Meteorologische Zeitschrift, v. 22, n. 6 , p. $711-728,2013 b$.

BRANDES, A. F. N.; NOVELLO, B. Q.; DOMINGUES, G. A. F.; BARROS, C. F; TAMAIO, N. Endangered species account for $10 \%$ of Brazil's documented timber trade. Journal for Nature Conservation, v. 55, I2582 I, 2020.

BRASIL. Presidência da República. Decreto No 6.472, de 5 de junho de 2008: Altera $\circ$ art. $3^{\circ}$ do Decreto $n^{\circ} 4.722$, de 5 de junho de 2003, que estabelece critérios para exploração da espécie Swietenia Macrophylla King (mogno). Available at: < http://www. planalto.gov.br/ccivil_03/_Ato2007-2010/2008/Decreto/ D6472.htm\#: : :text=DËCRETO\%20N\%C2\%BA\%20 $6.472 \% 2$ C\%20DE\%205, Swietenia\%20Macrophylla\%20 King\%20(mogno) >. Acess in: 18 jul. 2020.

CASAROLI, D.; ROSA, F. O.; ALVES JÚNIOR, J.; EVANGELISTA, A. W. P.; BRITO, B. V.; PENA, D. S. Aptidão edafoclimática para o mogno africano no Brasil. Ciência Florestal, v. 28, n. I, p. 357-368, 2018.

CAO, Y.; CARVER, S.; YANG, R. Mapping wilderness in China: Comparing and integrating Boolean and WLC approaches. Landscape and Urban Planning, v. 192, 103636, 2019.

CHAIKAEW, P.; ADEYEMI, O.; HAMILTON, A. O.; CLIFFORD, O. Spatial characteristics, and economic value of threatened species (Khaya ivorensis). Scientific Reports, v. I0, e6266, 2020. 
CHISIKA, S. N.; YEOM, C. The key factors affecting tree producer associations involved in private commercial forestry in Kenya. Sustainability, v. I2, 40I3, 2020.

CONSERVATOIRE ET JARDIN BOTANIQUES DE LA VILLE DE GENÈVE (CBJG) AND SOUTH AFRICAN NATIONAL BIODIVERSITY INSTITUTE (SANBI). African plant database. 20I2. Available at: < https:/www.ville-ge.ch/ musinfo/bd/cjb/africa/ recherche.php >. Access in: 30 jul. 2020.

COUTO, J. M. F.; OTONI, W. C.; PINHEIRO A. L.; FONSECA E. P. Desinfestação e germinação in vitro de Swetenia macrophylla King. Revista Árvore, v. 28, n. 5, p. 633-642, 2004.

DIPELET G. U. B.; DOUMENGE, C.; LOUMETO, J. J.; FLORENCE, J.; GONMADJE, C.; MCKEY, D. B. Des confusions entre espèces préjudiciables à la gestion durable des essences forestières: l'exemple des acajous d'Afrique (Khaya, Meliaceae). Bois et Forêts des Tropiques, v. 339, p. 17-32, 2019.

FALESI, I. C.; BAENA, A. R. C. Mogno-africano (Khaya ivorensis A. Chev.) em sistema silvipastoril com leguminosa e revestimento natural do solo. Embrapa Amazônia Oriental, 1999. 52p. Available at: < https:// www.infoteca.cnptia.embrapa. br/infoteca/bitstream/ doc/388796/I/OrientalDoc4.pdf >. Access in: I apr. 2020.

FARR, T.G.; KOBRICK, M. Shuttle Radar Topography Mission produces a wealth of data. American Geophysical Union Eos, v. 8I, p. 583-585, 2000

FREEMETEO. Tempo meteorológico e climas para cidades, vilarejos e topônimos no mundo. Available at: $<$ https://freemeteo.com.br > Access in: 25 jul. 2020.

GASPAROTTO, L.; HANADA, R.E.; ALBUQUERQUE, F.C.; DUARTE, M.L.R. Mancha areolada causada por Thanatephorus cucumeris em mogno africano. Fitopatologia brasileira, v. 26, n. 3, p.660-66I, 200I.

GOLFARI, L.; CASER, R. L.; MOURA. V. P. G. Zoneamento ecológico e esquemático para reflorestamento no Brasil (2a aproximação). PRODEPEF, 1978. 66p.

GRATTAPAGLIA, D.; KIRST, M. Eucalyptus applied genomics: from gene sequences to breeding tools. New Phytologist, v. |79, n. 4, p. 9|।-929, 2008.

IBÁ. Indústria Brasileira de Árvores. Relatório Anual: Ano Base 2018. Brasília: IBÁ, 2019. 80p. Available at: $<$ https://iba.org/datafiles/publicacoes/ relatorios/ibarelatorioanual2019.pdf > . Access in: 5 apr. 2020.

IBGE. Instituto Brasileiro de Geografia e Estatística. Malha de municípios. Rio de Janeiro, 2018. Available at: $<$ https://www.i bge.gov.br/geociencias/organizacaodo-territorio/estrutura-territorial/ I 5774-malhas. html?=\&t=downloads $>$. Access in: 20 feb. 2020.

INMET. Instituto Nacional de Metereorologia. Available at: < http://www.inmet.gov. br/portal/ > Access in: 20 feb. 2020.
INPE. Instituto Nacional de Pesquisas Espaciais. Estimativas anuais desde 1988: taxa de desmatamento anual $\left(\mathrm{km}^{2} /\right.$ ano). São José dos Campos: 2006. Available at: < http:// www.obt.inpe.br/prodes/prodes_1988_2005.htm >. Access in: I apr. 2020.

IPEF. Instituto de Pesquisas Florestais. Köppen Brasil 2013. Piracicaba: 2020. Available at: < www.ipef.br/geodatabase. $>$. Access in: 10 feb. 2020.

ITTO. International Tropical Timber Orghanization. Tropical Timber Market Report. Yokohama, v. 24, 2020. Available at: < https://www.itto.int/ > . Access in: 21 jul. 2020.

IUCN. International Union for Conservation of Nature and Natural Resources. IUCN Red List 2018. Cambridge, 2018. Available at: <https://www.iucnredlist.org > . Access in: 21 abr. 2020.

JARVIS, A.; REUTER, H. I.; NELSON, A.; GUEVARA, E. Holefilled SRTM for the globe: version 4. Available from the CGIAR-CSI SRTM 90 m Database: data grid, 2008. Available at: < http://srtm.csi.cgiar.org >. Access in: I apr. 2019.

KÖPPEN, W.; GEIGER, R. Klimate der Erde. Verlag Justus Perthes, 1928. Wall-map $150 \mathrm{~cm} \times 200 \mathrm{~cm}$.

KOTTEK, M.; GRIESER, J.; BECK, C.; RUDOLF, B.; RUBEL, F. World Map of the Köppen-Geiger climate classification updated. Meteorologische Zeitschrift, v. I5, n. 3, p. 259263, 2006.

KRISNAWATI, H.; KALLIO, M.; KANNINEN, M. Swietenia macrophylla King: ecology, silviculture and productivity. CIFOR, 20II. 24p. Available at: < http://www.cifor.org/ publications/pdf files/Books/BKrisnawatil 104.pdf >. Access in: 20 apr. 2020.

LAMPRECHT, H. Silvicultura nos trópicos: ecossistemas florestais e respectivas espécies arbóreas: possibilidades e métodos de aproveitamento sustentado. Deutsche Gessellschaft für Technische Zusammenarbeit, 1990. 343 p.

LEMES, M. R.; ESASHIKA, T.; GAOUE, O. G. Microsatellites for mahoganies: Twelve new loci for Swietenia macrophylla and its high transferability to Khaya senegalensis. American Journal of Botany, v. 98, e207-e209, 20II.

LEMES, P. G.; ZANUNCIO, A. J. V.; OLIVEIRA, L. S.; MATOS, M. F.; LEITE, G. L. D.; SOARES, M. A.; ZANUNCIO, J. C.; ASSIS JÚNIOR, S. L. Hypsipyla grandella (Lepidoptera: Pyralidae) boring Khaya ivorensis (Meliaceae) fruits and seeds in Brazil: first report. Florida Entomologist, v. 102 , p. $266-269,2019$

LEMMENS, R. H. M. J. Khaya ivorensis. In: LOUPPE, D.; OTENG-AMOAKO, A. A.; BRINK, M. (Ed.). Plant resources of tropical Africa. PROTA Foundation, 2008. Available at: < https://uses.plantnet-project.org/en/Khaya ivorensis\%20(PROTA)>. Access in: 2 apr. 2020. 
MAROYI, A. Khaya anthotheca. In: LOUPPE, D.; OTENGAMOAKO, A. A.; BRINK, M. (Ed.). Plant resources of tropical Africa. PROTA Foundation, 2008. Available at: $<$ https://uses.plantnet-project.org/en/Khaya_anthotheca (PROTA) >. Access in: 2 apr. 2020.

MATOS, F. S.; SILVEIRA, P. S.; BARRETTO, V. C. M.; FREITAS, I. A. S.; ARAUJO, M. S.; CALIXTO JUNIOR, J. E. D.; RIOS, J. M. Growth of Khaya senegalensis plant under water deficit. African Journal of Agricultural Research, v. II, p. I623- 1628, 2016.

NIKIEMA, A.; PASTENAK, D. Khaya senegalensis. In: LOUPPE, D.; OTENGAMOAKO, A. A.; BRINK, M. (Ed.). Plant resources of tropical Africa. PROTA Foundation, 2008. Available at: <https://uses.plantnet-project.org/en/Khaya senegalensis_(PROTA)>. Access in: 4 apr. 2020.

NIKLES, D. G.; BEVEGE, D. I.; DICKINSON, G.R.; GRIFFITHS M.W.; REILLY, D. F.; LEE, D. J. Developing African mahogany (Khaya senegalensis) germplasm and its management for a sustainable forest plantation industry in northern Australia: progress and needs. Australian Forestry, v. 7I, p. 33-47, 2008.

OPUNI-FRIMPONG, E.; KARNOSKY, D. F; STORER, A. J.; ABENEY, E.A.; COBBINAH, J. R. Relative suscepbility of four species of African Mahogany to the shoot borer Hypsipyla robusta (Lepdoptera: Piralidae) in the moist semideciduos forest of Ghana. Forest Ecology and Management, v. 255, p. 3| 3-3। 9, 2008.

OPUNI-FRIMPONG, E.; TEKPETEY, S. L.; OWUSU, S. A.; OBIRI, B. D.; APPIAH-KUBI, E.; OPOKU, S.; NYARKODUAH, N. Y.; ESSIEN, C.; OPOKU, E. M.; STORER, A. J. Managing mahogany plantation in the tropics: field guide for farmers. Forest Institute of Ghana, 2016. 95 p. Available at: < https://www.itto.int/ files/itto_\%20project db_input/2936/Technical/PD528-08Revl (F)-M̄ain-TechRepMahogany\%\%2020Book.pdf > . Access in: 21 apr. 2019.

PAKULL, B.; EKUÉ, M. R. M.; DIPELET, U. G. B.; DOUMENGE, C.; MCKEY, D. B.; LOUMETO, J. J.;OPUNI-FRIMPONG, E.; YOROU, S. N.; NACOULMA, B. M. Y.; GUELLY, K. A.; RAMAMONIISOA, L.; THOMAS, D.; GUICHOUX, E.; LOO, J.; DEGEN, B. Genetic diversity and differentiation among the species of African mahogany (Khaya spp.) based on a large SNP array. Conservation Genetics, v. 20, p. I035-1044, 2019.

PALMER, D.; GOTTSCHALG, R.; BETTS, T. The future scope of large-scale solar in the UK: Site suitability and target analysis. Renewable Energy, v. I33, p. I|36-I|46, 20 I9.

PAYN, T.; CARNUS, J. M.; FREER-SMITH, P.; KIMBERLEY, M.; KOLLERT, W.; LIU, S.; ORAZIO, C.; RODRUIGUEZ, L.; SILVA, L. N.; WINGFIELD, M. J. Changes in planted forests and future global implications. Forest Ecology and Management, v. 352, p. 57-67, 2015.

POLTRONIERI, L. S.; ALBUQUERQUE, F. C.; TRINDADE, D. R.; DUARTE, M. L. R. Detecção de Phamerochaete salmonicolor em Mogno Africano no Estado do Pará. Fitopatologia Brasileira, v. 27, n. 3, p. 32I-32I, 2002.

PRACIAK, A.; PASIECZNIK, N.; SHEIL, D.; VAN HEIST, M.; SASSEN, M.; CORREIA, C. S.; DIXON, C.; FYSON, G.; RUSHFORD, K.; TEELING, C. (Ed.). The CABI encyclopedia of forest trees. CABI, 20I3. 523 p.
QGIS Development Team. QGIS Geographic Information System. Open Source Geospatial Foundation Project. Available at: <http://qgis.osgeo.org > Access in: 20 jul. 2020.

REIS, C. A. F.; KALIL FILHO, A. N.; AGUIAR, A. V.; MORAESRANGEL, A. C. Caracterização das espécies pertencentes ao gênero Khaya de interesse no Brasil. In REIS, C. A. F.; OLIVEIRA, E. B.; SANTOS. A. M. Mogno-africano (Khaya spp.): atualidades e perspectivas do cultivo no Brasil. Brasília: Empresa Brasileira de Pesquisa Agropecuária. 2019a. p. 13-50.

REIS, C. A. F.; OLIVEIRA, E. B.;SANTOS. A. M. Mogno-africano (Khaya spp.): atualidades e perspectivas do cultivo no Brasil. Embrapa. 2019b. 379p. Available at: < https://www. embrapa.br/ busca-de-publicacoes/-/publicacao/I I I2698/ mogno-africano-khaya-spp-atualidade-e-perspectivas-docultivo-no-brasil >.Access in: 3 apr. 2020.

RIAD, P. H. S.; BILLIB, M.; HASSAN, A. A.; SALAM, M. A.; EL DIN, M. N. Application of the overlay weighted model and boolean logic to determine the best locations for artificial recharge of groundwater. Journal of Urban and Environmental Engineering, v. 5, p. 57-66, $20 \mathrm{II}$.

RIBEIRO, A.; FERRAZ FILHO, A. C.; OLIVEIRA, E. B. Usos, importância econômica e perspectivas de mercado. In REIS, C. A. F.; OLIVEIRA, E. B.; SANTOS. A. M. Mognoafricano (Khaya spp.): atualidades e perspectivas do cultivo no Brasil. Brasília: Embrapa. 2019. p. I3-50.

RIBEIRO, A.; FERRAZ FILHO, A. C.; SCOLFORO, J. R. S. O cultivo do mogno africano (Khaya spp.) e o crescimento da atividade no Brasil. Floresta e Ambiente, n. 24, p. I- I I, 2017.

SANTOS, H. G.; JACOMINE, P. K. T.; ANJOS, L. H. C.; OLIVEIRA, V. A.; LUMBRERAS, J. F;; COELHO, M. R.; ALMEIDA, J. A.; ARAUJO FILHO, J. C.; OLIVEIRA, J. B.; CUNHA, T. J. F. Sistema brasileiro de classificação de solos. Embrapa, 2018. $356 \mathrm{p}$

SEXTON, G. J.; FRERE, C. H.; KALINGANIRE, A.; UWAMARIYA, A.; LOWE, A. J.; GODWIN, I. D.; PRENTIS, P. J.; DIETERS, M. J. Influence of putative forest refugia and biogeographic barriers on the level and distribution of genetic variation in an African savannah tree, Khaya senegalensis (Desr.) A. Juss. Tree Genetic Genomes, v. II, p. I03-II5, 2015.

SOARES, S. D.; BANDEIRA, L.F.; RIBEIRO, S. B.; TELLES, M. C. P.; SILVA, J. A.; BORGES, C. T.; COELHO, A. S. G.; NOVAES, E. Genetic diversity in populations of African mahogany (Khaya grandioliola C. DC.) introduced in Brazil. Genetics and Molecular Biology, v. 43, n. 2, e20I80 I62, 2020.

THEOBALD, D.M. GIS Concepts and ArcGIS Methods. $3^{a}$ ed. Conservation Planning Technologies, 2012. 222p.

WATSON, J. J. W.; HUDSON, M. D. Regional Scale wind farm and solar farm suitability assessment using GISassisted multi-criteria evaluation, Landscape and Urban Planning, v. I38, p. 20-31, 2015. 
ZANETTI, R.; ABREU, C. S.; SILVEIRA, S. H. P.; ANDRADE, E. D. First report of Hypsipyla grandella (Lepidoptera: Pyralidae) on African mahogany Khaya ivorensis. Scientia Agricola, v. 74, p. 492-494, 2017.
ZHANG, B.; YANG, S. P.; YIN, S.; ZHANG, C. R.; WU, Y.; YUE, J. M. Limonoids from Khaya ivorensis. Phytochemistry, v. 70, p. I305-I308, 2009. 